\title{
The Orientation of Entrepreneurship : Determinant And Impact For Young Entrepreneurship Performance with Web
}

\author{
Titi Nugraheni ${ }^{1}$, Tety Elida ${ }^{2}$, Misdiyono ${ }^{3}$ \\ Gunadarma University, Indonesia, Faculty of Economics ${ }^{1,2,3}$ \\ \{titi_n@staff.gunadarma.ac.id ${ }^{1}$, tety@staff.gunadarma.ac.id², \\ misdie@staff.gunadarma.ac.id $\left.{ }^{3}\right\}$
}

\begin{abstract}
This study investigates the relationship of personal characteristics for online entrepreneur, internal environment and external environment to the orientation online entrepreneur and business performance. This study also analyzed the role of web quality on the relationship of business orientation and entrepreneurial performance. Data used are primary data, collected through questionnaires to online entrepreneurship students at 4 Universities in Jakarta, Bogor, Depok, Tangerang and Bekasi. The sample size taken is 273 online entrepreneurship students. Data processed descriptively, and using SEM (Structural Equation Modeling) AMOS 23 Program. The results indicate that the characteristics of personal, internal environment and external environment have a positive effect on the orientation of the online entrepreneur. Furthermore, the online student orientation has a positive effect on the performance with the quality of the web as a moderating variable.
\end{abstract}

Keywords: entrepreneurship; business performance; external and internal environment; web quality.

\section{Introduction}

A large number of unemployed people, especially educated unemployment and the lack of entrepreneurs in Indonesia, will have an impact on the emergence of various problems in society[1],[2] due to the increase in unemployment, such as poverty and crime [3]. There needs to be the prevention of these problems, among others by conducting entrepreneurship debriefing in the campus environment by providing facilities for online entrepreneurship and increasing mastery of internet technology among students so that students can develop their potential related to mastering technology [4] especially the internet and become a tool to encourage students to be more creative and innovative and in the end will trigger students to be motivated to become entrepreneurs with web-based or online entrepreneurship.

Based on field observations, there are currently many students who do business by becoming online entrepreneurs driven by several factors, among others because of personal characteristics, internal factors and external factors [4],[5],[6] and ultimately affect the orientation and concept of online business of students. Available websites that can be used by students to conduct online business activities require the right strategy so that e- commerce 
portals meet quality web standards.[7],[8] so that it will affect the performance of their business.[9]

This study uses web quality measurements that have been developed on the concept of Quality Function Deployment (QFD)[7], which is a web measurement method that is based on web users (voice of customer) assessment in developing and implementing products and services which refers to the service quality model[8]. This research is important considering the greater opportunities for entrepreneurship among students, especially to foster entrepreneurship based online and as an effort to reduce the number of educated unemployed through the use of technology provided by universities and government as facilitators to create a better online business performance for the future than in general this study aims to identify personal characteristics, external and internal factors that influence the entrepreneurial orientation of students and to assess the relationship or mechanism of personal characteristics, external and internal factors in influencing business performance.

\section{Literature Review}

Consumer Behavior on E-Commerce. The theory of consumer behavior [10] is the study of how individuals make decisions to allocate available resources such as time, money, effort and energy.[11] Consumers have a very unique diversity with various ages, cultural backgrounds, education, economic conditions, ethnicities and others. Business people think it is necessary to learn how consumers behave. Business people study consumer behavior and what factors influence this behavior. [12], with influencing factors: cultural factors, social factors, personal factors and psychological factors. Consumer behavior can also be influenced by stimulation from the marketing mix such as product, price, promotion and distribution factors [11] which greatly supports changes in e-commerce concepts.[13]

\section{1 Entrepreneur Characteristic, Performance and Web Quality}

Entrepreneur Characteristic. Entrepreneurship is someone who can create something new and different through creative thinking and innovative actions for the sake of creating opportunities, improving existing products/services, finding new ways to get more products with more efficient resources. [14],[15]Personal characteristics (individual) include age, gender, years of service, level of education, ethnicity, and personality. Individual characteristics are individual traits inherent in a person and related to aspects of life, including age, gender, position, position, social status, and religion. Entrepreneurial orientation is also influenced by the internal environment in the future.[16],[17],[18] Training and diverse ethnic origins in Indonesia will bring ethnic traditions when entrepreneurship is an important contribution of entrepreneurship to company performance [19],[20] and the dimensions that determine the characteristics of entrepreneurial orientation are autonomy, innovation, willingness to take risks, proactive, and aggressive competition (autonomy, innovativeness, risk-taking, proactiveness, competitive aggressiveness so that entrepreneurial orientation can be measured from three dimensions namely proactiveness, risk-taking, and innovativeness. Company performance is a measure of success in making effective and efficient decisions on the utilization of company resources for business continuity. [21],[22],[23] and greatly influence online entrepreneurial businesses. [5] Performance. Performance is influenced by the internal environment and external environment for the development of its business. $[16],[6],[24],[17]$ Indicators to measure the performance of a business unit or organization are 
revenue growth (market recovery), market share (market share), profitability, the overall performance (overall performance), a satisfaction of shareholders (stakeholder satisfaction).[25],[26],[27] and in e-commerce to measure performance is through 3 (three) things, namely efficiency, coordination and trade. [21],[28],[9],[29]

Web Quality. Website quality theory (WebQual) is one method of measuring website quality developed by Barnes and Vidgen. [30] The size of web quality can be measured using: Accessibility, Currency, Accuracy and Credibility, can also be measured using information quality: Relevancy, Sufficiency, Understandability, Customer service efficiency: Careful, Continuous, Ease of navigation, Content layout, Ease of use.[8],[31],[32].

\subsection{Research Framework.}

Based on previous studies, it is necessary to review this web quality variable whether it is possible to moderate the causal relationship between entrepreneurial orientation and business performance, the framework of this research is as in the following figure.

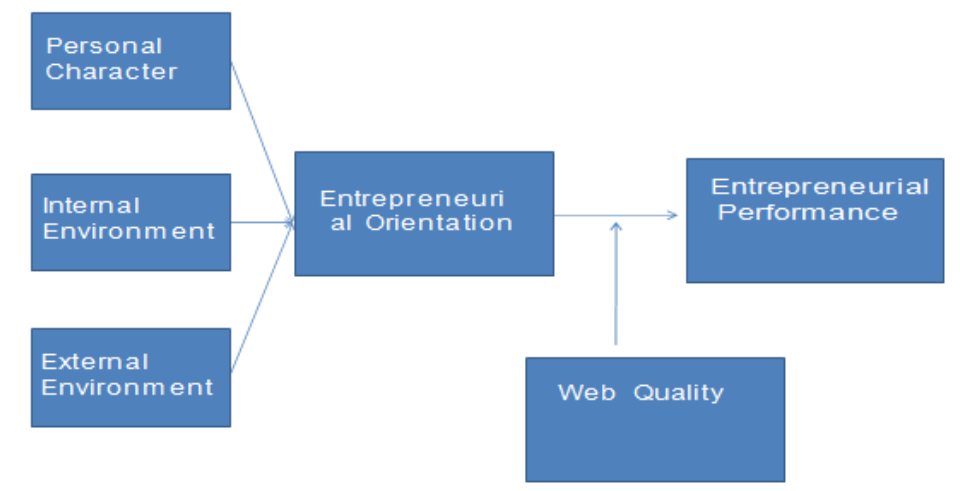

Fig. 1. Research Framework

\section{Methods}

The survey was conducted on 273 respondents who were students and had online businesses from several universities in Jakarta, Bogor, Depok, Tangerang and Bekasi (Jabodetabek) areas. Based on observations through the college page, and based on the ranking of the top 20 Webometrics 2016 it is known that many students who have online businesses are spread in 4 Universities for the Jabodetabek region, including the University of Indonesia, Gunadarma University, Bogor Agricultural Institute and Bina Nusantara University.

The sample criteria in this study are all students who have an online business, with a minimum length of business of 1 year. Guidelines for determining sample size for Structural Equation Modeling (SEM) according to Haier [33] in studies using 22 indicators, the recommended number of samples was at least $22 \times 10$ or 220 respondents. The suitability analysis of the model in this study uses Structural Equation Modeling (SEM) using AMOS 23. Program. First, make estimates without entering interaction variables. At this stage, the value of variable factor loading value is calculated Orientation of Entrepreneurship and Business Performance. The second stage calculates the loading factors and variants of the 
interaction variable between Online Entrepreneur Orientation and Web Quality. The third stage, then estimating the model by adding interaction variables and factor loading values

Some of the variables measured in this study are as follows: Personal characteristics variables are measured based on background, ethnic origin, business experience, entrepreneurial entrepreneurship training experience [5],[34],[18],[4],[24]. Internal Environment Variables are measured through financial aspects of the respondent, technology, production, market and marketing aspects [18],[24],[4],[6]. External Environment Variables, measured by Government policies relating to entrepreneurship, socio-cultural conditions of society and the role of universities and other related institutions [6],[24],[16],[4] Entrepreneurial Orientation variables are measured based on attitude to innovate, proactive attitudes and risk attitudes [16],[34],[6]. Web Quality Variables are measured based on web accessibility, the accuracy of the information, services and Web security [8],[7],[35],[36],[31]. Variable Business Performance is measured based on market development conditions, development of production and the level of efficiency of respondents. [5],[37],[38],[39],[40].

\section{Results and Discussion}

\subsection{Characteristics of the Sample}

Findings in the field, the number of male respondents $(20 \%)$ is less compared to female entrepreneurs online (74\%). This shows that the motivation to become an online entrepreneur is dominated by female students. The ever-changing percentage of entrepreneurs online male and female students shows that to become entrepreneurs, gender is not the main requirement, because being an entrepreneur is essentially having to have a spirit of independence, a high entrepreneurial spirit and this applies to all people regardless of gender someone. The age of respondents is dominated by respondents who have an age range of 20 years to 23 years which is equal to $78 \%$ of the total number of respondents. The number of respondents who are less than 19 years old is $19 \%$ of the total respondents 273 people. This proves that the enthusiasm for becoming an online entrepreneur has started a lot at a young age. Some respondents stated that since high school they had started online entrepreneurship. Factors that make the motivation of respondents start online entrepreneurship because they want to have pocket money from their efforts other than other factors such as wanting to gain business experience or socializing experience. The number of respondents is based on Javanese ethnic, 35\%; mixed ethnicity, 32\%; Sundanese ethnic $17 \%$, Minang ethnic $6 \%$ and as many as $8 \%$ of respondents came from ethnic Arabic, Batak, and Lampung. This finding shows that students from Javanese ethnic have the motivation to become bigger entrepreneurs. Besides being known to be tenacious in working like ethnic Chinese, Javanese have a very close socializing culture. This is what underlies some Javanese ethnicities who have managed to become entrepreneurs. Instagram media user respondents, 83\%; Facebook, 34\%; Web alone 4.3\%; Bukalapak, $12.08 \%$; Blog, $4.2 \%$;

Twitter, 9.52\%; Tokopedia, 13.9\%; OLX, 3.66\%; BBM, $13.9 \%$ and other media users, $0.36 \%$. Respondents prefer Instagram as a medium that is used for entrepreneurship, in addition to the Web portal from campus, because Instagram has easy-to-understand and interesting features to use and seeks to use online media for its business so that profits will always increase, and e-commerce activities become more developed. Products sold by respondents included fashion, $47.3 \%$; accessories, $20.8 \%$; bag, $9.9 \%$; handmade crafts, $5.01 \%$; 
toys, $22.3 \%$ and others such as herbs, facial masks, cosmetics, frozen food, sports equipment, supplements, milk pudding, honey, medicines, 4.4\%. Fashion products rank most. Respondents as online sellers prefer fashion products because most of the customers are teenagers who like changing clothing models, the market for fashion products is still very profitable.

Source of respondent's business capital originating from own capital, 67\%; capital financial from parents, $26 \%$; other sources, $5.49 \%$. stated that the business capital to do business online came from other sources, such as funds obtained through collecting capital jointly with his friends. The average turnover is less than Rp1,000,000 (65\%); between Rp. 1,000,000 - Rp. 4,000,000, 31\%; between Rp. 5,000,000 to Rp. 10,000,000, 2\%; above

$10,000,000,1.09 \%$. Based on the results of surveys and interviews with respondents, the sales turnover they receive is very volatile depending on the type of product, price, service and promotion through social media. Orientation to the local market, 78\%; National market, 18\%; international market, $3.3 \%$. But they were optimistic that someday they would also soon penetrate national and international markets.

\subsection{Equation Model Analysis}

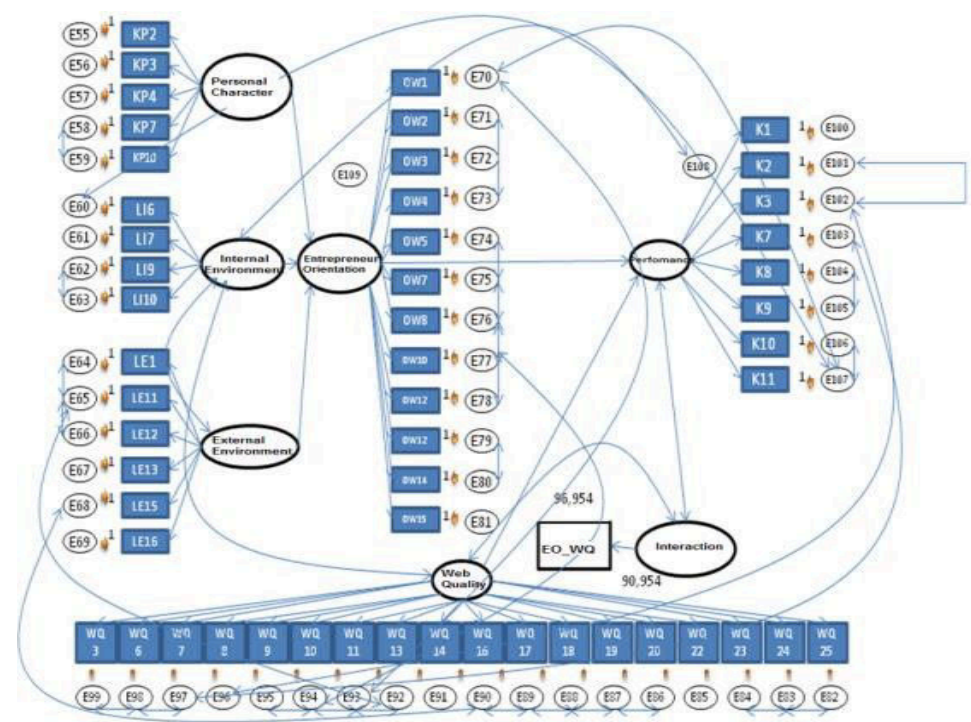

Fig. 2. Results of measurements on the Research Model

Results of the Test of the Effect of Personal Characteristics, Internal Environment and External Environment on Entrepreneurship Orientation:

$\mathrm{EO}=0.101 \mathrm{KP}+0,617 \mathrm{LI}+0,272 \mathrm{LE}+0,010$

Based on the equation above shows the personal characteristics, external environment and internal environment influence the entrepreneurial orientation conducted resulting in a determination correlation coefficient value $\mathrm{R}^{2}=0.465$; and achieved at the significance level of Sig. $=0,000$. The coefficient of determination 0.465 can be seen that the model equation (1) 
formed is quite good because the model formed can explain that $46.5 \%$ of the variation in entrepreneurial orientation is influenced by personal characters, the external environment and the internal environment together. While $43.5 \%$ is influenced by other factors outside of this study, such as age, political conditions, taxes and others. Personal characteristics have a positive effect on student entrepreneurship orientation of $10.1 \%$ with a significance value of 0,000 , which means that the family background of online entrepreneurial students plays an important role in motivating and shaping the character of entrepreneurship. (Hypothesis accepted). The origin of ethnic entrepreneurship is an important factor in the formation of entrepreneurial character. An entrepreneur who comes from a certain ethnicity will bring out his ethnic nature when doing business. Ethnic Chinese and Javanese are the most dominating ethnic groups in Indonesia because they are very persistent in doing business. In addition to personal characteristics, internal environmental factors have an important role as much as $71 \%$ in influencing students' entrepreneurial orientation while external factors are $27 \%$. Formulation of the test results of the influence of entrepreneurial orientation on business performance:

$\mathrm{P}=0.341 \mathrm{EO}+0.659$

The online entrepreneurial orientation in doing business influences business performance by $43.7 \%$. Thus, other factors that influence business performance by $56.3 \%$. Other factors referred to, were not analyzed in this study, such as the attitude to increase market share, aggressiveness in developing online businesses and so on. Hypothesis test results show there is a positive relationship with a correlation of 0.341 Sig.0,000. (Hypothesis accepted).[34]State that proactive need to be developed by companies when in conditions of uncertainty. Formulation of the results of Web Quality Influence Test as Moderating Entrepreneurship Orientation on Business Performance shows the role of web quality as a variable that moderates the relationship between entrepreneurial orientation and business performance:

$\mathrm{P}=0.228 \mathrm{EO}+0.519(\mathrm{EO} * \mathrm{WQ})+0,455$

Student orientation and Web quality have a positive effect on business performance with a determinant coefficient of 0.545 . There was an increase in the relationship between entrepreneurial orientation and business performance after web quality moderated by $0.24 \%$. This means that in this study web quality variables are moderating, which strengthens the relationship between entrepreneurial orientation and business performance. The hypothesis test shows there is a positive relationship with Sig. 0,000. (Hypothesis accepted). This finding is reinforced by the results of web quality will affect customers, affecting which will ultimately affect sales and performance turn over.[35],[41],[42],[7],[43]

\subsection{Results of Hypothesis Test}

First hypothesis:Personal character influences entrepreneurial orientation. In this study, it is evident that the financial aspects, ethnic origin and business experience of online entrepreneurs can influence the personal characteristics of online entrepreneurs in determining online business. The findings of this discovery are supported by [34],[44],[18]. The second hypothesis: The internal environment influences the entrepreneurial orientation of students.

In this study, it is empirically proven that financial aspects, technological factors, 
operations and production, market aspects and marketing have a positive effect on online entrepreneurial orientation in managing attitudes toward business risk, ability to innovate and ability to have a proactive attitude towards possible business risks. The results of this discovery are supported by [17],[24],[16]

Third hypothesis: External environment influences student entrepreneurial orientation. This study empirically proves that the role of the government, the economic condition of the community, the role of related institutions in this case the higher education institution has a positive influence on the ability of students to respond to all business risks, the ability to innovate and the ability of students to be proactive in facing the possibility of online business risks. The role of government, society and universities in shaping the character of entrepreneurs who have an online business orientation will certainly influence online entrepreneurship performance. The results of this discovery are supported by [45],[46],[23],[2]

The fourth hypothesis: Online entrepreneurial orientation has a positive effect on business performance. The findings in this study are empirically proven that online entrepreneurial proactive attitudes, innovation orientation and the ability to address all online business risks have a positive influence on increasing sales, increasing sales turnover, an increasing number of customers, increasing online entrepreneurship product marketing networks. These findings are also supported by [47],[48],[49]

Fifth hypothesis: Student entrepreneurial orientation influences online entreprene rship performance with web quality as a moderator. The findings in this study are empirically proven that web quality is a variable that moderates the relationship between entrepreneurial business orientation and online entrepreneurial performance. The findings are also supported by [50],[51]

\section{Conclusion}

Personal characteristics consisting of family background, training, ethnic origin and business experience; internal environment consisting of dimensions of financial aspects, technological and production aspects, market aspects and marketing; and the external environment which consists of dimensions of government policy aspects, social, cultural, and economic aspects that have a positive effect on entrepreneurial orientation. The personal characteristics of an increasingly advanced entrepreneur are balanced with the development of internal factors and the support of the external environment which will affect the orientation of his entrepreneurial online business. Online entrepreneurial orientation consisting of dimensions of proactive attitude, innovation, attitudes in dealing with business risk has a positive effect on business performance. The more advanced the online entrepreneurial orientation in managing business risk, the ability to have a proactive and balanced attitude with high innovation ability influences online entrepreneurship performance. The quality of the web is measured using dimensions of web accessibility, the accuracy of the information, quality of service features, and quality of security features have a positive effect on business performance. The quality of the web can be said as moderating the causal relationship between entrepreneurial orientation and business performance.

\section{References}

[1] M.Yelubayeva, A. Mironov, L. Kharchenko, and O. Putecheva, "Aspects of the current 
problems of society in contemporary art," Opcion, vol. 35, no. Special Issue 23, pp. 547-562, 2019.

[2] I. Kostetska and I. Berezyak, "Management Theory and Studies for Rural Business and Infrastructure Development SOCIAL ENTREPRENEURSHIP AS AN INNOVATIVE SOLUTION MECHANISM OF SOCIAL PROBLEMS OF SOCIETY," Manag. Theory Stud. Rural Bus. Infrastruct., vol. 36, no. 3, pp. 1822-6760, 2014, [Online]. Available: file://C:/Users/Kristina/AppData/Local/Temp/849-1715-1-SM-1.pdf.

[3] M. Hooghe, B. Vanhoutte, W. Hardyns, and T. Bircan, "Unemployment, inequality, poverty and crime: Spatial distribution patterns of criminal acts in Belgium, 2001-06," Br. J. Criminol., vol. 51, no. 1, pp. 1-20, 2011, doi: 10.1093/bjc/azq067.

[4] M. Munizu, "Pengaruh Faktor-Faktor Eksternal dan Internal Terhadap Kinerja Usaha Mikro dan Kecil (UMK) di Sulawesi Selatan," J. Manaj. dan Wirausaha, vol. 12, no. 1, pp. 33-41, 2010, doi: 10.9744/jmk.12.1.pp.33-41.

[5] L. M. Uhlaner, F. W. Kellermanns, K. A. Eddleston, and F. Hoy, "The entrepreneuring family: A new paradigm for family business research," Small Bus. Econ., vol. 38, no. 1, pp. 1-11, 2012, doi: 10.1007/s11187-010-9263-x.

[6] J. A. G. Tengtarto, "Influences of Internal Environment, External Environment, Business Ethics and Entrepreneurship Toward Business Performances Through Differentiation Strategies and Competing Superiorities in Small Industries in Surabaya City," Arch. Bus. Res., vol. 8, no. 1, pp. 138-151, 2020, doi: 10.14738/abr.81.7551.

[7] P. B. GovindAarajan and A. R. Krishnan, "A Study on Influence of Web Quality and Self Efficacy on Massive Open Online Courses (MOOCs) Technology Adoption by Extending the Utaut Model with Reference to Student MOOC Users," Shanlax Int. J. Manag., vol. 7, no. 2, pp. 47-53, 2019, doi: 10.34293/management.v7i2.820.

[8] T. Ahn, S. Ryu, and I. Han, "The impact of Web quality and playfulness on user acceptance of online retailing," Inf. Manag., vol. 44, no. 3, 2007, doi: 10.1016/j.im.2006.12.008.

[9] K. L. Kraemer and J. Gibbs, "Impacts of globalization on E-commerce use and firm performance: A cross-country investigation," Inf. Soc., vol. 21, no. 5, pp. 323-340, 2005, doi: 10.1080/01972240500253350.

[10] K. Z. K. Zhang and M. Benyoucef, "Consumer behavior in social commerce: A literature review," Decis. Support Syst., vol. 86, pp. 95-108, 2016, doi: 10.1016/j.dss.2016.04.001.

[11] P. Kotler, Marketing Management, 5 th. Prentice- Hall, 2016.

[12] Schiffman LG, Consumer Behavior, 10th ed. Pearson Education, 2010.

[13] A. P. Shemi and C. Procter, "E-commerce and entrepreneurship in SMEs: case of my Bot,” J. Small Bus. Entrep. Dev., vol. 25, no. 3, 2018, doi: 10.1108/JSBED-03-20170088.

[14] F. Isada, H. C. Lin, and Y. Isada, "Entrepreneurship of university students in Taiwan and Japan," Manag. Res. Rev., vol. 38, no. 12, pp. 1251-1266, 2015, doi: 10.1108/MRR-06-2014-0131.

[15] S. L. Nielsen and W. B. Gartner, "Am I a student and/or entrepreneur? Multiple identities in student entrepreneurship," Educ. Train., vol. 59, no. 2, pp. 135-154, 2017, doi: 10.1108/ET-09-2014-0122.

[16] R. C. Becherer, D. Halstead, and P. Haynes, "Marketing Orientation in SMEs: Effects of the Internal Environment," J. Res. Mark. Entrep., vol. 3, no. 1, pp. 1-17, 2001, doi: $10.1108 / 14715200180001474$.

[17] M. Zain and N. M. Kassim, "The Influence of Internal Environment and Continuous 
Improvements on Firms Competitiveness and Performance," Procedia - Soc. Behav. Sci., vol. 65, no. ICIBSoS, pp. 26-32, 2012, doi: 10.1016/j.sbspro.2012.11.086.

[18] H. Littunen, "Entrepreneurship and the characteristics of the entrepreneurial personality," Int. J. Entrep. Behav. Res., vol. 6, no. 6, pp. 295-310, 2000, doi: $10.1108 / 13552550010362741$.

[19] N. M. Wahyuni and I. M. Sara, "The effect of entrepreneurial orientation variables on business performance in the SME industry context," J. Work. Learn., vol. 32, no. 1, 2020, doi: 10.1108/JWL-03-2019-0033.

[20] S. Dewi and A. Ahamat, "The role of entrepreneurial orientation in achieving organization performance through business model innovation and asset relational collaboration," Humanit. Soc. Sci. Rev., vol. 6, no. 2, 2018, doi: 10.18510/hssr.2018.6212.

[21] J. Huang, X. Jiang, and Q. Tang, “An e-commerce performance assessment model: Its development and an initial test on e-commerce applications in the retail sector of China," Inf. Manag., vol. 46, no. 2, 2009, doi: 10.1016/j.im.2008.12.003.

[22] S. Sidek, M. R. Mohamad, and W. M. N. W. M. Nasir, "Sustaining Small Business Performance: Role of Entrepreneurial Orientation and Financial Access," Int. J. Acad. Res. Bus. Soc. Sci., vol. 9, no. 9, 2019, doi: 10.6007/ijarbss/v9-i9/6270.

[23] C. Sekhar, M. Karthikeyan, A. Divakaran, and Z. Deyi, "Performance of e-Commerce business in India and China," Int. J. Agric. Sci., vol. 15, no. 1, 2019, doi: 10.15740/has/ijas/15.1/195-211.

[24] S. Indris and I. Primiana, "Internal And External Environment Analysis On The Performance Of Small And Medium Industries Smes In Indonesia," Int. J. Sci. Technol. Res., vol. 4, no. 4, pp. 188-196, 2015.

[25] E. Joseph, "Mall performance: Corporate, retail, restaurants and e-commerce effects," Int. J. Financ. Res., vol. 10, no. 2, 2019, doi: 10.5430/ijfr.v10n2p1.

[26] H. Cuevas-Vargas, N. Parga-Montoya, and R. Fernández-Escobedo, "Effects of Entrepreneurial Orientation on Business Performance: The Mediating Role of Customer Satisfaction-A Formative-Reflective Model Analysis," SAGE Open, vol. 9, no. 2, 2019, doi: 10.1177/2158244019859088.

[27] Z. Papulová and J. Papula, "Entrepreneurship in the Eyes of the Young Generation," Procedia Econ. Financ., vol. 34, no. 15, pp. 514-520, 2015, doi: 10.1016/s22125671(15)01662-7.

[28] J. K. Kinyua, R. Gakure, M. Gekara, and G. Orwa, "Effect of Internal Control Environment on the Financial Performance of Companies Quoted in the Nairobi Securities Exchange," Int. J. Innov. Financ. Econ. Res., vol. 3, no. 4, 2015.

[29] S. O. Adebiyi, B. B. Amole, K. A. Arikewuyo, and O. G. Oyenuga, "Multi-Criteria Decision Analysis of Entrepreneurial Orientation and Business Performance in Nigeria," Econ. Bus., vol. 33, no. 1, 2019, doi: 10.2478/eb-2019-0010.

[30] Barnes JS and Vidgen TR, An Integr. Approach Electron. Commer., vol. 3, no. 3, 2002.

[31] W. Liu, A. Sidhu, A. M. Beacom, and T. W. Valente, "Social Network Theory," Int. Encycl. Media Eff., pp. 1-12, 2017, doi: 10.1002/9781118783764.wbieme0092.

[32] J. K. R. Sastry, N. Sreenidhi, and K. Sasidhar, "Quantifying quality of WEB site based on usability," Int. J. Eng. Technol., vol. 7, no. 2.7 Special Issue 7, 2018, doi: 10.14419/ijet.v7i2.7.10606.

[33] B. J. B. Joseph F. Hair, William C. Black, Rolph E. Anderson, Multivariate Data Analysis, 8th, illustr ed. Cengage, 2018, 2018.

[34] G. T. Lumpkin and G. G. Dess, "Academy of Management Heview," Acad. Manag. 
Rev., vol. 21, no. 1, pp. 135-172, 1996.

[35] U. Akram, P. Hui, M. Kaleem Khan, Y. Tanveer, K. Mehmood, and W. Ahmad, "How website quality affects online impulse buying: Moderating effects of sales promotion and credit card use," Asia Pacific J. Mark. Logist., vol. 30, no. 1, pp. 235-256, 2018, doi: 10.1108/APJML-04-2017-0073.

[36] A. M. Shaltoni, "From websites to social media: exploring the adoption of internet marketing in emerging industrial markets," J. Bus. Ind. Mark., vol. 32, no. 7, pp. 10091019, 2017, doi: 10.1108/JBIM-06-2016-0122.

[37] A. Tajudin, R. Abdul Aziz, R. Mahmood, and M. H. Abdullah, "The Relationship between Entrepreneurial Orientation and Business Performance of SMEs in Malaysia," Int. J. Manag. Excell., vol. 2, no. 3, 2014, doi: 10.17722/ijme.v2i3.96.

[38] S. Vij and H. S. Bedi, "Relationship Between Entrepreneurial Orientation and Business Performance: A Review of Literature.," IUP J. Bus. Strateg., vol. 9, no. 3, 2012.

[39] L. M. Habeeb, B. A. A. Ghali, and T. H. K. Alharguse, "The relationship between entrepreneurial orientation and business performance: Exploring the moderating role of supply chain management in SME sector of Iraq," Int. J. Supply Chain Manag., vol. 8, no. 2, 2019.

[40] Y. Zhang and X. Zhang, "The effect of entrepreneurial orientation on business performance: A role of network capabilities in China," J. Chinese Entrep., vol. 4, no. 2, 2012, doi: 10.1108/17561391211242744.

[41] Farida, I. Suyudi, Nuryuliani, and B. Hermana, "A Review of Empirical Research on Website Quality Measurement Model Based On Consumer's Perception,” Int. Conf. Internet Stud., no. December 2015, pp. 1-13, 2014.

[42] M. Bitler, "Small Business and Computers: Adoption and Performance," Fed. Reserv. Bank San Fr. Work. Pap. Ser., pp. 1.000-48.000, 2001, doi: 10.24148/wp2001-15.

[43] A. Galati, M. Crescimanno, S. Tinervia, and D. Siggia, "Website quality and internal business factors: An empirical investigation in the Italian wine industry," Int. J. Wine Bus. Res., vol. 28, no. 4, pp. 308-326, 2016, doi: 10.1108/IJWBR-08-2015-0026.

[44] B. Sumantri, A. Fariyanti, and R. Winandi, "Faktor-Faktor yang Berpengaruh terhadap Kinerja Usaha Wirausaha Wanita: Suatu Studi pada Industri Pangan Rumahan di Bogor," J. Manaj. Teknol., vol. 12, no. 3, pp. 252-277, 2013, doi: 10.12695/jmt.2013.12.3.3.

[45] S. Feizollahi, A. Shirmohammadi, Z. S. Kahreh, and M. S. Kaherh, "Investigation the Effect of Internet Technology on Performance of Services Organizations with ecommerce Orientations," Procedia - Soc. Behav. Sci., vol. 109, 2014, doi: 10.1016/j.sbspro.2013.12.514.

[46] N. Candra Astuti and R. A. Nasution, "Technology Readiness and E-Commerce Adoption among Entrepreneurs of SMEs in Bandung City, Indonesia," Gadjah Mada Int. J. Bus., vol. 16, no. 1, pp. 69-88, [Online]. Available: http://www.gamaijb.mmugm.ac.id/.

[47] K. R. Cantaleano, G. P. Rodrigues, and T. S. Martins, "The mediating effect of proactive market orientation capability in entrepreneurial orientation and service innovation," Rev. Adm. Mackenzie, vol. 19, no. 1, 2018, doi: 10.1590/16786971/eRAMR180038.

[48] Musthofa, S. Wahyudi, N. Farida, and Ngatno, "Effect of entrepreneurial orientation on business performance," Int. J. Civ. Eng. Technol., vol. 8, no. 9, 2017, doi: $10.1108 / 17561391211242744$.

[49] G. Kaur and S. Mantok, Effects Of Entrepreneurial Orientation ON BUSINESS 
PERFORMANCE: A STUDY OF SSIs IN LUDHIANA,” J. Serv. Res., vol. 15, no. 1, 2015.

[50] "EXAMINING MODERATING ROLE OF E-COMMERCE EXPERIENCE ON USAGE-PERFORMANCE RELATIONSHIP," Asia Pacific J. Adv. Bus. Soc. Stud., vol. 4, no. 2, 2018, doi: 10.25275/apjabssv4i2bus3.

[51] R. Hernández-Linares, F. W. Kellermanns, M. C. López-Fernández, and S. Sarkar, The effect of socioemotional wealth on the relationship between entrepreneurial orientation and family business performance, BRQ Bus. Res. Q., 2019, doi: 10.1016/j.brq.2019.03.002. 